\title{
Natan Jagoan (Bina Duta Anti Jajanan Sembarangan) With Methods of Food Display and Educational Videos As Well As Healthy Snacks Ladder Snake Game
}

\author{
Masrul $^{1}$, Yulizawati ${ }^{2}$, Rika Susanti ${ }^{3}$, Ony Devega ${ }^{2}$, Tiara Sukma ${ }^{2}$, Feby Surya ${ }^{2}$ \\ masrulmuchtar@med.unand.ac.id ${ }^{1}$ \\ ${ }^{1}$ Department of Nutrition, Faculty of Medicine, Universitas Andalas, Padang, Indonesia \\ ${ }^{2}$ Bachelor of Midwifery Program Faculty of Medicine Universitas Andalas, Padang, Indonesia \\ ${ }^{3}$ Division of Forensic and Medicolegal, Faculty of Medicine, Universitas Andalas, Padang, \\ Indonesia
}

\begin{abstract}
Behavior buying haphazard food is still a problem that must be paid attention by all parties. This behavior is a lot owned by the students of the school especially elementary school students are still very superficial knowledge about healthy snacks and unhealthy for consumption. The cheap snacks, flavorings, and wear colored usually a favorite of students to eat it. "NATAN JAGOAN (biNa duTa Anti jaJAnan sembaranaGAN) with methods of Food Display and Educational Videos as well as Healthy Snacks Ladder Snake Game at 20 Alang Lawas Elementary School" that will be held for 4 months in an effort to enhance the knowledge of students in identifying the kinds of healthy snacks and other types of unhealthy snacks and can be role models as Ambassadors of Anti unhealthy snacks for the environment and their friends. The purpose of this service is to educate elementary school students about healthy snacks and avoid dangerous snacks with Food Display and Educational Video methods as well as Healthy Snack Ladder Games. The implementation phase of the activity began with surveys and permits, pre-activity questionnaires, peer education, post-activity questionnaires, and the creation of service articles. The service carried out at SDN 20 Alang Lawas, Padang went smoothly and found an increase in attitudes for students and knowledge for teachers and parents about healthy and careless snacks. The target of dedication was also considered to be able to become an Ambassador of Anti-unhealthy Snacks for the environment and other elementary school children.
\end{abstract}

Keywords: Natan Jagoan, Methods, Healhty

\section{Introduction}

Food is a source of energy and a variety of nutrients to support human life, but food can also be a source of disruptive health, when things are consumed unsafe (Badan POM, 2012).

Snack food safety problems that are often encountered in school environments are caused by processed food products in school environments that are contaminated with hazardous substances (microbiological and chemical hazards), ready-to-eat foods in the school environment that do not meet hygiene requirements, and problematic food donations. Child snacks surveillance survey in 2013 with 5,668 school samples showed a decrease in excess food additives. The decline occurred from $24 \%$ in 2012 , to $17 \%$ in 2013. But microbial contamination increased from $66 \%$ last year to $76 \%$ now (Badan POM, 2013).

WHO estimates that there are around 2 million victims, especially children, who die every year due to unsafe food. For this reason parents must be smart consumers so that they can protect themselves and their families from dangerous food drinks. (Badan POM, 2013).

This is possible because many children buy hawker foods that are careless and unhealthy. Primary school age children tend to choose cheap snacks in the form of ice or cakes, usually 
the cheaper the price of an item or the lower the quality of the food as well as the use of food ingredients that are less good and usually already contaminated by germs or using additional synthetic substances so the food is durable or interesting. Currently there are many children affected by diarrhea because children generally ignore the cleanliness of the food they eat. Primary school-age children generally do not necessarily understand the meaning of health for their bodies (Carmen, 2011).

BPOM West Sumatra province according to the results of a 2016 survey conducted in each regency and city of 882 samples tested, found 18 samples containing hazardous ingredients such as Boraks and Rhodamin B. In the same year 13 extraordinary outbreaks of food poisoning occurred. , where 8 cases occurred at school. In 2017 three cases of outbreaks of food poisoning were found, two of which occurred in elementary schools. (Badan POM, 2015).

Special attention from all parties regarding this unhealthy snack needs attention from various parties so that the problem of outbreaks caused by snacks that are not suitable for consumption can decrease and the health of elementary school students can be further enhanced so that the catching power of material received during school will be increasingly good (Dodik Briawan, 2016)

Elementary schools were selected to represent the city of Padang is the 20 Alang Lawas Elementary School located at Jalan Bagindo Azis Chan No.4, Belakang Pondok Village, South of Padang district. The condition of the area in SDN 20 Alang Lawas is quite strategic because it is located in the city center. In addition, the school environment that joins several other schools causes a lack of supervision by the school for students who are unhealthy food snacks in the school environment (Khusna N,Setiaji HB,Sahli Z .2014)

From the initial survey, it was found that $5 \%$ of all students experienced diarrhea every month. While in terms of economics $75 \%$ of parents of students work as traders. For that the program carried is NATAN JAGOAN (biNa duTa Anti jaJAnan sembaranGAN) with methods of Food Display and Educational Videos as well as Healthy Snacks Ladder Snake Game to realize these efforts.

\section{Methods}

The "NATAN JAGOAN" activity program will be carried out after preparation and licensing are complete. Activities will be carried out in 20 Alang Lawas Elementary School located at Jalan Bagindo Azis Chan No.4, Belakang Pondok Village, South of Padang district. Subjects in elementary school are students consisting of grade 4 students, and grade 5 students. The "NATAN JAGOAN" program is conducted for 4 months involving several partners from the school. The 4th and 5th grade students will be given training through the Food Display method and Video Education performance as well as the Healthy Snack Ladder Snake game with the aim of attracting students' attention and students can easily absorb the information provided in a fun way. At the beginning of the activity, students will be given a questionnaire (pre-test) to find out the students' knowledge about healthy snacks. After all activities have been carried out for 2 months, the final data will be taken regarding the level of students' knowledge with giving (post-test).

"NATAN JAGOAN" Program Method:

a. Education Video

The video displayed in the form of illustrations that explain healthy foods in general, types and characteristics of healthy and unhealthy foods, tips on choosing healthy snacks to prevent them from buying snacks.

b. Food Display 
Food Display is a visual communication that can be seen directly the difference between healthy and unhealthy snacks by directly displaying various kinds of school snacks. Students can also hold, see, smell and touch the food to see the difference significantly.

c. Healthy Snack Ladders

In this snake ladder game there are pictures that characterize healthy snacks and unhealthy snacks. on the stairs up and down and the snake's head and tail will be filled with various types of images of healthy snacks and unhealthy snacks where the images displayed form the cause and effect of the food consumed and the food caused. In the game if the student is on the stairs down or up, the student must guess the type of snacks found in the picture and convey the opinion of why the snacks are good or not good for consumption. This Snake Ladder Game is also equipped with a question card that contains various questions about knowledge about healthy and unhealthy snacks consumption and the impact that has been impacted as well as daily healthy living behavior.

Evaluation of the impact of activities on participants will be seen through field observations and observations to determine whether participants are able to become role models or not for the environment or their friends. The evaluation phase also focused on the analysis of the questionnaires that had been collected. Furthermore, for the sustainability of the program an evaluation is conducted every 3 months to the school and the chosen anti-unhealthy snack ambassadors.

\section{Result}

The implementation of PKM-M Natan Jagoan (biNa duTA anTi Jajanan sembaraNGAN) with the method of Food Display and Education Video and Snake Games Ladder at SDN 20 Alang Lawas, Padang can be considered as going well. The first step in this program is the initial location survey, the purpose of which is to identify the problems in the institution and how to solve the problem or alternative solutions. Furthermore, community service with the school. The response from the school is very good and very supportive of the program that will be carried out because according to them the formation of anti-snack ambassadors is arbitrary so students know healthy and unhealthy snacks. After the preparatory phase is complete, a thorough evaluation of the preparatory phase is carried out.

Table 1. Results of Achievement Evaluation for the Activity Preparation Phase

\begin{tabular}{|c|c|c|c|}
\hline \multirow[t]{2}{*}{ No } & \multirow[t]{2}{*}{ Activity } & \multicolumn{2}{|c|}{$100 \%$ achievement } \\
\hline & & Done & $\begin{array}{c}\text { Not implemented } \\
\text { yet }\end{array}$ \\
\hline 1. & The survey places the implementation activities & $100 \%$ & - \\
\hline 2. & $\begin{array}{l}\text { Administration and licensing of community } \\
\text { service places }\end{array}$ & $100 \%$ & - \\
\hline 3. & $\begin{array}{l}\text { Making educational videos and evaluation } \\
\text { questionnaires }\end{array}$ & $100 \%$ & - \\
\hline 4. & Preparation of food display & $100 \%$ & - \\
\hline 5. & Snake ladder design & $100 \%$ & - \\
\hline & Achievement of the activity preparation phase & $100 \%$ & - \\
\hline
\end{tabular}


This service activity was officially opened on Thursday, April 26, 2018 by the Secretary of SDN 20 Alang Lawas, Padang and officially closed on Tuesday, June 26, 2018 after the dedication of the service activities in 3 meetings with different activities first on April 26, 2018 material presentation with the Video Education media method and material presentation through Power Point. The second activity was held on May 14, 2018 with the Media Food Display method in which the Food Display of more than 15 types of healthy and unhealthy snacks was displayed and explained in detail by a facilitator (elder mentor). The third activity is also a method for learning fun, namely playing Snakes and Ladders. Healthy snacks are considered to have absorbed the material well in the first and second activities. Therefore, the results of the absorption of these two activities will be evaluated in the snake ladder healthy game. because students will answer the questions listed on the question card to be the best and reach the finish first delivered with the Food Display media method.

Table 2. Results of Students' Pre-Knowledge Sub-Activity Questionnaire Evaluation

\begin{tabular}{lcccc}
\hline No & $\begin{array}{c}\text { Classification of } \\
\text { Questionnaire Assessment }\end{array}$ & $\begin{array}{c}\text { Total } \\
\text { Target } \\
\text { Value }\end{array}$ & $\begin{array}{c}\text { Number of } \\
\text { participants }\end{array}$ & $\begin{array}{c}\mathbf{1 0 0 \%} \\
\text { achievement }\end{array}$ \\
\hline 1 & Low & $1-10$ & 5 & $11,9 \%$ \\
2 & Moderate & $11-13$ & 19 & $45,23 \%$ \\
3 & High & $14-17$ & 18 & $42,85 \%$ \\
\hline Total & & & 42 & $100 \%$ \\
\hline
\end{tabular}

Table 3. Post Questionnaire Evaluation Results - Student Sub Knowledge activities

\begin{tabular}{ccccc}
\hline No & $\begin{array}{c}\text { Classification of } \\
\text { Questionnaire Assessment }\end{array}$ & $\begin{array}{c}\text { Total } \\
\text { Target } \\
\text { Value }\end{array}$ & $\begin{array}{c}\text { Number of } \\
\text { participants }\end{array}$ & $\begin{array}{c}\mathbf{1 0 0 \%} \\
\text { achievement }\end{array}$ \\
\hline 1 & Low & $1-10$ & 1 & $2,3 \%$ \\
2 & Moderate & $11-13$ & 10 & $23,80 \%$ \\
3 & High & $14-17$ & 31 & $73,8 \%$ \\
\hline & Total & & 42 & $100 \%$ \\
\hline
\end{tabular}

From the evaluation table the pre and post questionnaires generated an increase in students' knowledge after all methods were given. For low results it dropped from $11.9 \%$ to $2.3 \%$, the yield was down $45.23 \%$ to $23.80 \%$ and for high yields rose from $42.85 \%$ to $73.8 \%$.

Table 4. Results of Evaluation of Pre-Activity Questionnaire for Sub Attitudes of Students

\begin{tabular}{ccccc}
\hline No & $\begin{array}{c}\text { Classification of } \\
\text { Questionnaire Assessment }\end{array}$ & $\begin{array}{c}\text { Total } \\
\text { Target } \\
\text { Value }\end{array}$ & $\begin{array}{c}\text { Number of } \\
\text { participants }\end{array}$ & $\begin{array}{c}\mathbf{1 0 0 \%} \\
\text { achievement }\end{array}$ \\
\hline 1 & Positive & $\geq 63,7$ & 21 & $55,21 \%$ \\
2 & Negative & $\leq 63,7$ & 17 & $44,73 \%$ \\
\hline Total & & & 38 & $100 \%$ \\
\hline
\end{tabular}


Table 5. Results of Evaluation of Post-Activity Questionnaire for Sub-Attitudes of Students

\begin{tabular}{|c|c|c|c|c|}
\hline No & $\begin{array}{c}\text { Classification of } \\
\text { Questionnaire Assessment }\end{array}$ & $\begin{array}{c}\text { Total } \\
\text { Target } \\
\text { Value } \\
\end{array}$ & $\begin{array}{l}\text { Number of } \\
\text { participants }\end{array}$ & $\begin{array}{c}100 \% \\
\text { achievement }\end{array}$ \\
\hline 1 & Positive & $\geq 66,6$ & 25 & $65,78 \%$ \\
\hline 2 & Negative & $\leq 66,6$ & 13 & $34,21 \%$ \\
\hline Total & & & 38 & $100 \%$ \\
\hline
\end{tabular}

From the evaluation table, it is known that there is an increase in parental attitudes where the mean data rises when compared to the pre and post evaluation results of 63.7 to 66.6 and also the positive attitude of student guardians regarding healthy snacks also increased.

Table 6. Evaluation Results of the Teacher's Sub Attitude Pre-Activity Questionnaire

\begin{tabular}{ccccc}
\hline No & $\begin{array}{c}\text { Classification of } \\
\text { Questionnaire } \\
\text { Assessment }\end{array}$ & $\begin{array}{c}\text { Total } \\
\text { Target } \\
\text { Value }\end{array}$ & $\begin{array}{c}\text { Number of } \\
\text { participants }\end{array}$ & $\begin{array}{c}\mathbf{1 0 0 \%} \\
\text { achievement }\end{array}$ \\
\hline 1 & Positive & $\geq 80$ & 4 & $44,4 \%$ \\
2 & Negative & $\leq 80$ & 5 & $55,5 \%$ \\
\hline
\end{tabular}

Table 7. Evaluation Results of the Post-Activity Sub-Attitude Teacher's Questionnaire

\begin{tabular}{lcccc}
\hline No & $\begin{array}{c}\text { Classification of } \\
\text { Questionnaire } \\
\text { Assessment }\end{array}$ & $\begin{array}{c}\text { Total } \\
\text { Target } \\
\text { Value }\end{array}$ & $\begin{array}{c}\text { Number of } \\
\text { participants }\end{array}$ & $\begin{array}{c}\mathbf{1 0 0 \%} \\
\text { achievement }\end{array}$ \\
\hline 1 & Positive & $\geq 83,8$ & 6 & $66,6 \%$ \\
2 & Negative & $\leq 83,8$ & 3 & $33,3 \%$ \\
\hline
\end{tabular}

In tables 6 and 7 the results of the evaluation of the sub attitude questionnaire of teachers also multiply the increase in mean data and positive attitudes about healthy snacks. The following is the exhaustion of the output targets of the service carried out at SDN 20 Alang Lawas, Padang.

Table 8. Achievement of Target Outcomes

\begin{tabular}{llcc}
\hline No & \multicolumn{1}{c}{ Target } & \multicolumn{1}{c}{$\mathbf{1 0 0 \%}$ achievement } \\
\cline { 3 - 4 } & & done & $\begin{array}{c}\text { Not implemented } \\
\text { yet }\end{array}$ \\
\hline 1 & $\begin{array}{l}\text { Getting the Food Display method as a fun } \\
\text { teaching method }\end{array}$ & - \\
2 & $\begin{array}{l}\text { Healthy and unhealthy snacks education videos } \\
\text { to support activities } \\
\text { Get Healthy Snack Ladder Snake Game method } \\
\text { for fun teaching methods } \\
\text { Creating young cadres who succeed in the } \\
\text { activities of "NATAN JAGOAN!" } \\
\text { Community service articles published in local } \\
\text { print media }\end{array}$ & $100 \%$ & - \\
\hline \multicolumn{1}{c}{ Achievement of Target Outcomes } \\
\hline
\end{tabular}




\section{Discussion}

The behavior of buying snacks at random is still a problem that must be considered by all parties. This behavior is widely owned by school students, especially elementary school students whose knowledge is still very shallow about healthy snacks and not healthy for consumption. Cheap snacks, using flavoring, and attractive colors are usually the prima donna of elementary students to eat. Supervision and lack of school attention to this cause unhealthy snacks are more easily consumed by students. As a result of the rise of unhealthy snacks this affects the health of students and cognitive development of students.

\section{Conclusion}

From the problems caused by these unhealthy snacks, we propose a program entitled "NATAN JAGOAN" (biNA duTa Anti Jajanan sembaranGAN) with Food Display Methods and Educational Video and Healthy Snack Ladder Snakes at 20 Alang Lawas Elementary School that will be carried out during 4 months as an effort to increase students' knowledge in recognizing the types of healthy snacks and types of unhealthy snacks and can be role models as Ambassadors of Anti unhealthy Snacks for the environment and their friends.

Conclusions from the results of the questionnaire evaluation there was an increase in student knowledge and attitudes of the teacher and student guardian significantly.

\section{References}

Badan POM. 2012. Booklet 5 Kunci Keamanan Pangan untuk Anak Sekolah. Direktorat Surveilan dan Penyuluhan Keamanan, Deputi Bidang Pengawasan Keamanan Pangan dan Bahan Berbahaya. Jakarta

BPOM RI.2013. Buku Pedoman Pangan Jajanan Anak Sekolah Untuk Pencapaian Gizi Seimbang.Jakarta

BPOM RI 2015 Bahaya Rhodamin B Sebagai Pewarna Pada Pangan website.pom.go.id. 19 april 2015

BPOM.2009.Pengawasan Obat dan Makanan 2009.Food Watch sistem terpadu keamanan pangan jajanan anak sekolah.Vol 1.Jakarta

Carmen.2011.Pengetahuan,sikap dan perilaku tentang gizi seimbang pada anak sekolah dasar.Studi multi senter oleh sepuluh perguruan tinggi di berbagai kota di Indonesia 20092011.Ditjen Pendidikan Tinggi Kemendikbud

Dodik Briawan.2016.Perubahan Pengetahuan,sikap,dan Praktik Jajajanan Anak Sekolah Dasar Peserta Program Edukasi Pangan Jajanan.J.Gizi Pangan. diakses November 2016

Khusna N,Setiaji HB,Sahli Z .2014.Pengaruh Penyuluhan tentang jajanan sehat terhadap pengetahuan dan sikap anak usia sekolah dasar .Jurnal Kesehatan 5(10:44-49) 